\title{
Trandolapril je vhodnou volbou u hypertoniků s metabolickým syndromem či s rizikem rozvoje diabetu a u pacientů se srdečním selháním po infarktu myokardu
}

Zvýšení inzulinové senzitivity pozorované u trandolaprilu a neutrální vliv na další metabolické parametry při jeho kombinaci s verapamilem předurčuje tuto kombinaci k léčbě hypertoniků s metabolickým syndromem (MS). Díky preventivním účinkům proti vzniku a progresi diabetu je kombinace trandolapril + verapamil vhodná také u hypertoniků, kteří mají diabetes nebo vysoké riziko jeho vzniku. Morbi-mortalitní studie u pacientů po infarktu myokardu (IM) se srdečním selháním prokázaly přínos inhibitorů enzymu konvertujícího angiotensin (ACEI) (včetně trandolaprilu), beta-blokátorů a blokátorů aldosteronu. Výběru správné léčby pro pacienty s hypertenzí na XXII. výročním sjezdu České kardiologické společnosti v květnu 2014 v Brně věnovali své přednášky prof. MUDr. Miroslav Souček, CSc. (II. interní klinika, LF MU a FN u sv. Anny, Brno), prof. MUDr. Štěpán Svačina, DrSc. (III. interní klinika, 1. LF UK a VFN, Praha) a prof. MUDr. Lenka Špinarová, Ph.D. (I. interní kardioangiologická klinika, LF MU a FN u sv. Anny, Brno).

\section{Kombinace trandolapril + verapamil SR má v léčbě hypertenze př́znivý profil metabolických účinků}

Většina hypertoniků potřebuje $\boldsymbol{k}$ dosažení cílových hodnot krevního tlaku (TK) dvě nebo více antihypertenziv $z$ různých tríd. Kombinace verapamilu s trandolaprilem vykazuje komplementární účinky na TK a má přiznivý profil metabolického působení. Jak objasnil prof. Souček, diky neutrálnímu vlivu obou těchto látek na lipidemii, neutrálnímu vlivu verapamilu na metabolismus cukrů a zlepšení inzulinové senzitivity při podávání trandolaprilu je tato kombinace vhodná u hypertoniků s MS.

Metabolický syndrom zvyšuje mortalitu pacientů 3,6násobně. Jeho prevalence v ČR dosahuje více než $30 \%$ u mužů a více než $20 \%$ u žen. Podíl hypertoniků s MS bude tedy značný. Prof. Souček přiblížil účastníkům symposia důvody, proč je u těchto pacientů vhodná právě kombinace verapamilu s trandolaprilem.

Účinky verapamilu a trandolaprilu na TK se vzájemně doplňuji, protože navozují vasodilataci různými mechanismy účinku, oba inhibují retenci sodíku a vody a zajištúuí účinnost u pacientů s nízkou (verapamil) i s vysokou (trandolapril) koncentrací reninu. Inhibitory enzymu konvertujícího angiotensin i blokátory Ca kanálů (BKK) mají synergické účinky na strukturu a funkci cév, především zlepšují poměr mezi tlouštkou stěny a lumen arteriol. Dále bylo prokázáno, že ACEI i BKK patří mezi třídy antihypertenziv, které omezují variabilitu TK. Variabilita TK je přitom významným prediktorem cévních mozkových příhod (CMP) i kardiovaskulárních (KV) príhod. Trandolapril i verapamil patří mezi antihypertenziva s nejvyšším pomèrem "trough/peak".

Přínos trandolaprilu u pacientů se složkami MS byl prokázán v řadě klinických studií. Čtyřletá léčba trandolaprilem významně snížila celkovou mortalitu diabetiků s dysfunkcí levé komory po IM. Ve studii BENEDICT vedla léčba trandolaprilem u diabetiků 2. typu během čtyř let ke snížení kumulativní incidence albuminurie o 53 \% ( $p=$ $0,01)$. Ve studii TRIS zajistilo podávání trandolaprilu u 90 hypertoniků s nadváhou významné zvýšení inzulinové senzitivity oproti vstupním hodnotám i oproti léčbě nifedipinem (obr. 1). Zvýšení inzulinové senzitivity př̀ léčbě trandolaprilem bylo potvrzeno také $v$ další studii $v$ porovnání $s$ atenololem $(p<0,05)$. $\vee$ této studii prokázal trandolapril na rozdíl od atenololu také neutrální vliv na koncentraci triglyceridů a HDL cholesterolu.

Verapamil patří mezi non-dihydropyridinové BKK s vyváženým účinkem na periferní $\mathrm{i}$ koronární vasodilataci. Nevede k reflexnímu zvýšení srdeční frekvence, kontraktility myokardu a spotřeby kyslíku a má omezené inotropní účinky. Ve studii VHAS, která porovnávala antihypertenzní účinek verapamilu SR a chlortalidonu, byla hodnocena

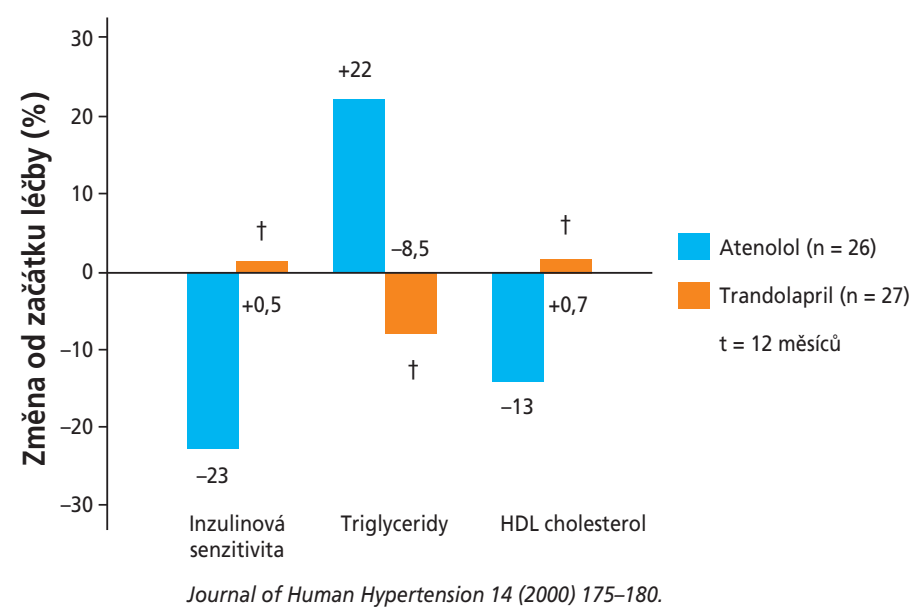

Obr. 1 - Srovnání účinku trandolaprilu a atenololu na inzulinovou senzitivitu a koncentraci lipidů u hypertoniků 
také regrese/progrese karotických lézí. Výsledky ukázaly významnější regresi karotických lézí a až o 50 \% nižší výskyt KV příhod ve skupině s verapamilem SR. V jiné studii bylo při podávání verapamilu SR v kombinaci s ACEI u diabetiků 1. typu s hypertenzí dosaženo nižšího výskytu albuminurie než při monoterapii každým z antihypertenziv.

Jak uzavřel prof. Souček, "kombinovanou antihypertenzní léčbu je třeba zahájit u pacientů, jejichž TK je více než 20/10 mm Hg nad cílovou hodnotou. Uvedená kombinace verapamil + trandolapril patří mezi doporučené preferované kombinace antihypertenziv: inhibitory systému renin-angiotensin + BKK, inhibitory systému renin-angiotensin + sulfonamidová diuretika nebo BKK + sulfonamidová diuretika. Vyhovuje také doporučením pro antihypertenzní léčbu v rámci KV prevence, která by zejména u osob s proaterogenním anebo prediabetickým stavem měla mít metabolicky příznivé účinky."

\section{Kombinace trandolapril + verapamil SR zlepšuje prevenci rozvoje diabetu u hypertoniků}

U hypertonikůs diabetes mellitus 2. typu (DM2T) nebo s rizikem jeho rozvoje má lékař možnost volit antihypertenziva s metabolicky neutrálním, nebo dokonce přiznivým účinkem. Prof. Svačina ve své přednášce připomenul, že fixní kombinace trandolaprilu s verapamilem SR je díky své metabolické neutralitě a příznivým účinkưm v prevenci vzniku a progrese DM2T vhodná právě u těchto pacientů. $V$ kombinované léčbě hypertenze u pacientů s rizikem rozvoje DM2T nebo s diabetem je díky metabolické neutralitě a zvýšení inzulinové senzitivity doporučován také moxonidin.

Diabetes mellitus 2. typu a hypertenze spolu vzájemně souvisejí. Glykemie je prediktorem rozvoje hypertenze, častěji ale hypertenze o několik let předchází vznik DM2T. Hypertonici mají 2,5krát vyšší riziko vzniku diabetu. V patogenezi rozvoje DM2T se u hypertoniků uplatňuje centrální sympatikotonie, retence tekutin a relativní hypervolemie. Pokud tedy lékař zjistí hypertenzi u nediabetika, měl by uplatnit pravidla prevence DM2T, sledovat jeho prípadný vznik a volit antihypertenziva na základě rizika diabetu.

V prevenci DM2T je třeba uplatnit zvýšení fyzické aktivity, redukci hmotnosti a zvýšení př́imu rostlinných tuků na úkor živočišných. Pokud se týká volby antihypertenziva, studie s ACEI (HOPE, CAPP, SOLVD, ALLHAT-ACE) shodně ukázaly snížení výskytu nových případů DM2T asi o 30-40 \%. Prokázaný účinek sartanů na prevenci diabetu u hypertoniků je nižší, asi $25 \%$ a efekt těchto dvou tříd antihypertenziv není aditivní. Vzájemnou souvislost hypertenze a DM2T ukázala i studie UKPDS. Výskyt IM i mikrovaskulárních příhod vykázal v této studii jasnou závislost na systolickém TK.

Studie BENEDICT prokázala možnost prevence vývoje mikroalbuminurie u DM2T. Sledovala incidenci mikroalbuminurie u 1204 diabetiků 2. typu s hypertenzí a normální albuminurií při podávání verapamilu SR a trandolaprilu samostatně nebo $v$ kombinaci v porovnání s placebem. Po čtyřech letech léčby byla incidence pretrvávající mikroalbuminurie významně nižší u fixní kombinace verapamilu SR a trandolaprilu ve srovnání s placebem $(5,7 \%$ vs. $10,0 \%, p=0,01)$.

Studie STAR porovnávala účinek kombinace trandolapril + verapamil SR $(T+V)$ a losartan + hydrochlorothiazid $(\mathrm{L}+\mathrm{H})$ na glukózovou toleranci u 240 hypertoniků s MS. Výsledky po jednom roce ukázaly, že fixní kombinace T + $\checkmark$ nezměnila glykemii ve 2 . hodině orálního glukózového tolerančního testu (oGTT) a snižila riziko nově vzniklého $D M 2 T$, zatímco fixní kombinace $L+H$ významně zvýšila glykemii ve 2 . hodině oGTT i riziko vzniku DM2T. V prodloužení studie STAR-LET, kde užívali všichni pacienti 26 týdnů kombinaci $T+V$, došlo ve skupině pacientů převedených na tuto kombinaci $k$ poklesu průměrné glykemie při oGTT oproti výchozímu stavu.

Příznivý vliv na metabolismus glukózy v léčbě hypertoniků Ize využít také u moxonidinu. Tento centrálně působící, selektivní agonista imidazolinových receptorů je metabolicky neutrální, a navíc prokázal zvýšení inzulinové senzitivity o $21 \%$ ve srovnání s placebem u obézních pacientů (BMI > 27) se středně závažnou hypertenzí. Evropské standardy proto doporučují moxonidin do kombinační terapie hypertoniků a hypertoniků s DM2T.

\section{Trandolapril splňuje všechny požadavky na léčbu pacientů po infarktu myokardu}

Na základè výsledků morbi-mortalitních studií by mèli být pacienti po IM se srdečním selháním léčeni ACEI (v prípadě intolerance sartanem), dále beta-blokátorem a blokátorem aldosteronu. U symptomatických pacientů se podává také diuretikum a v dlouhodobé léčbě má své místo kyselina acetylsalicylová. Prínos statinů ani remodelačních operací srdce z hlediska prognózy těchto pacientů nebyl prokázán. Trandolapril splňuje všechny požadavky na léčbu pacientů po IM a se srdečním selháním. Je vhodný u těchto pacientů i při současném výskytu hypertenze, DM2T nebo mírné až střední renální insuficience. Compliance s léčbou zvyšuje podávání trandolaprilu jednou dennè.

Pacient po IM je ohrožen rozvojem srdečního seIhání. Cílem léčby je odvrátit remodelaci levé komory (LK), zachovat její funkci. Výsledek závisí na včasnosti intervenčního zákroku i na průvodní a dlouhodobé farmakoterapii. Prínos z hlediska omezení remodelace LK prokázaly ACEI, u nichž je doloženo zlepšení funkce a zmenšení hmoty LK. Již starší krátkodobě pưsobící ACEI prokázaly při včasném podání po IM (do 24-48 hodin) relativní snížení mortality, které bylo v rozsáhlých studiích s moderními dlouhodobě působícími ACEI dosaženo i při pozdějším zahájení léčby po IM u pacientů se srdečním selháním a dysfunkcí LK. Metaanalýza studií SAVE (captopril), AIRE (ramipril) a TRACE (trandolapril) ukázala významné zlepšení prognózy pacientů po IM během čtyřleté léčby $A C E I$ v porovnání s placebem. Ve studii TRACE s pacienty po IM se sníženou funkcí LK vedla čtyřletá léčba trandolaprilem $k$ významnému snížení celkové mortality o 22 \% v porovnání s placebem (obr. 2). V prodlouženém sledování, kde všichni pacienti dostávali trandolapril, byl po 6, a dokonce i po 10-12 letech léčby stále patrný rozdíl ve střední době přežívání pacientů ve prospěch skupiny, která byla od počátku 


\section{Vysoce významné snížení celkové mortality o $22 \%$}

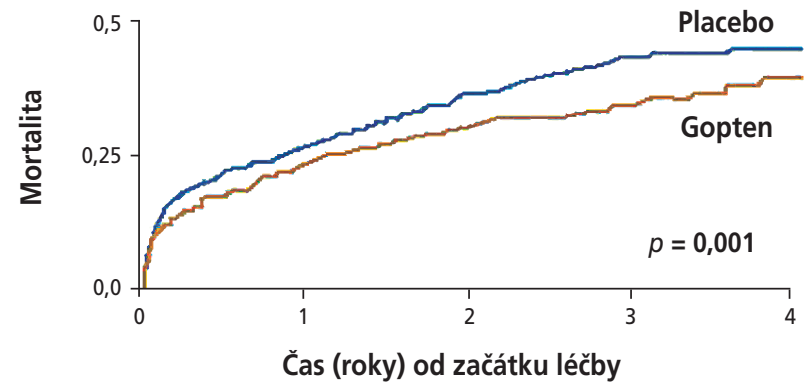

Obr. 2 - Snížení celkové mortality po čtyřech letech léčby pacientů po IM trandolaprilem ve studii TRACE

studie léčena ACEI. Rozdíl byl zjištěn i ve výskytu hospitalizací. To svědčí pro význam včasného zahájení léčby ACEI u pacientů po IM. Ve stejné studii zajistil trandolapril po čtyřech letech léčby o 55 \% nižší výskyt fibrilace síní, což naznačuje příznivý vliv ACEI také na odvrácení remodelace síní.

Studie OPTIMAAL ukázala podobný prínos sartanů u pacientů po IM. Ovšem kombinace sartanu s ACEI ne- vedla $k$ dalšímu snížení mortality pacientů po IM, naopak zvýšila výskyt nežádoucích účinků. Přidání selektivního blokátoru aldosteronu eplerenonu ve studii EPHESUS zajistilo další pokles celkové $\boldsymbol{i} \boldsymbol{K V}$ mortality i počtu hospitalizací. K léčbě pacientů po IM a pacientů se srdečním seIháním rozhodně patří beta-blokátory. Studie CAPRICORN prokázala významné snižení mortality pacientů po IM s dysfunkcí LK při podávání carvedilolu. Naopak přidání rosuvastatinu k optimální léčbě systolického srdečního selhání ischemické etiologie nevedlo po průměrné době sledování 2,7 roku k významnému zlepšení prognózy pacientů (KV mortalita, nefatální IM, nefatální CMP). Přínos rosuvastatinu dokonce klesal se zvyšující se závažností srdečního selhání. Proto u nemocných s chronickým srdečním selháním při systolické dysfunkci LK není dưvod zahajovat léčbu statiny. Pokud se srdeční selhání rozvine u pacientů, kteří statin užívají, je možné tento lék nahradit některým z prípravků s prokázaným účinkem na snížení mortality. Ani snaha o nefarmakologické ovlivnění remodelace LK se nesetkala s úspěchem. Ve studii STICH, která porovnávala implantace koronárního bypassu (CABG) a CABG + tzv. remodelační operaci, nezajistila kombinovaná intervence snižení sledovaných parametrů, jako je mortalita, hospitalizace z KV příčin, akutní IM či CMP.

MUDr. Zuzana Zafarová 